\title{
EVALUATION OF TREATMENT METHODS FOR ERADICATION OF PLANT PATHOGENS FROM CARROT SEED
}

\author{
L-H. CHEAH ${ }^{1}$ and S. OLSSON ${ }^{2}$ \\ ${ }^{1}$ Crop \& Food Research, Private Bag 11600, Palmerston North, New Zealand \\ ${ }^{2}$ HortResearch, Private Bag 92169, Mt Albert, Auckland, New Zealand
}

Corresponding author: cheahl@crop.cri.nz

Importation of seed is a risk pathway for the introduction of unwanted organisms to New Zealand, including pathogens, insects and weeds. These risks are managed by MAF BNZ through implementation of Import Health Standards, but information about the efficacy of some seed treatments is lacking. Alternaria leaf blight and Fusarium root rot of carrot (caused by Alternaria and Fusarium spp. respectively) are seedborne diseases and can cause seed losses of up to $50 \%$. Treatment methods tested for control of these diseases included: ozone (in gas or in water) at $10 \mathrm{ppm}$ for 10,30 and $60 \mathrm{~min}$ for each treatment; ionised copper water at $5 \mathrm{ppm}$ for 2, 4 and $8 \mathrm{~h}$; and hot water drench at 50 , 52.5 and $55^{\circ} \mathrm{C}$ for 15 and $30 \mathrm{~min}$ at each temperature. Treated seeds were plated on PDA with antibiotics and fungi growth assessed 5 days after incubation at $22^{\circ} \mathrm{C}$. None of the ozone and ionised copper water treatments reduced frequency of isolation of Alternaria and Fusarium spp. All hot water drench treatments (except $50^{\circ} \mathrm{C}$ for $15 \mathrm{~min}$ ) completely killed the fungi. These results indicate that hot water treatment is effective for control of Alternaria and Fusarium spp. on carrot seeds. The effect of hot water treatments on seed germination is being investigated.

\section{DATABASE TOOLS FOR RISK ANALYSIS OF FUNGAL PLANT PATHOGEN INCURSIONS INTO NEW ZEALAND}

\author{
K.R. EVERETT ${ }^{1}$, I.P.S. PUSHPARAJAH ${ }^{1}$, S.L.H. VILJANEN- \\ ROLLINSON $^{2}$ and M.V. MARRONI ${ }^{2}$
}

${ }^{I}$ The Horticulture and Food Research Institute of New Zealand Ltd. (HortResearch), Private Bag 92169, Mt Albert, New Zealand

${ }^{2}$ Crop \& Food Research, Private Bag 4704, Christchurch, New Zealand

Corresponding author: keverett@hortresearch.co.nz

A prototype database has been developed to provide an up-to-date New Zealandspecific resource for use by risk assessors. An updated list of biosecurity risk plant fungal pathogens has been compiled for apples, grapes, kiwifruit, barley, wheat and potato crops. Based on analysis of the literature, the most important factors for risk assessments for fungal plant pathogen incursions are, for rusts, proximity to New Zealand of the disease source and, for other fungi, the presence in the source country of biosecurity risk pathogens. Pathway analysis (including wind pattern modelling for rust incursions) is also an important component of risk assessment. For both groups of fungi, to determine the risk of establishment and invasiveness, the climatic parameters (temperature and humidity) for spore germination and infection are required. The economic impact of specific incursions has also been estimated. All these factors have been included in the database, and the risks of incursions have been calculated on this basis. 